\title{
Perilaku Ibu pada Pemberian Makanan Pendamping ASI (MPASI) di Kelurahan Pegirian
}

\author{
Maternal Behavior towards Complementary Feeding in Pegirian \\ Village
}

\author{
Santi Lestiarini ${ }^{1)}$, Yuly Sulistyorini ${ }^{2)}$ \\ ${ }^{1}$ Departemen Promosi Kesehatan dan Ilmu Perilaku, Fakultas Kesehatan Masyarakat, Universitas \\ Airlangga, Surabaya \\ 2 Departemen Biostatistika dan Kependudukan, Fakultas Kesehatan Masyarakat, Universitas \\ Airlangga, Surabaya \\ Email: santi.lestiarini-2016@fkm.unair.ac.id
}

\begin{abstract}
Background: The target of exclusive breastfeeding has not been achieved because complementary feeding (MPASI) has been given earlier. Infants aged 0-6 months should only get breastfed without any complementary food. Objective: This paper aimed to analyze factors related to maternal behavior towards complementary feeding (MPASI) in Pegirian Village. Method: This study was observational and cross-sectional, involving all mothers and caregivers of under-five-year-old children in Pegirian Village. The sample size was 35 mothers and caregivers of toddlers in Neighborhood Association No. 06 Community Association 02 Pegirian Village, Surabaya City. Sampling technique in use was saturated sampling or census method because the total population was less than 100 . The research variables included educational background, income, and actions in giving MPASI. Correlation test was in use to see the relationship among factors. Results: The results showed that there was a relationship between knowledge and attitude with complementary feeding behavior ( $P$ value $=0.001$ and 0.015 ). There was no relationship between the level of education and employment status with complementary feeding behavior towards infants aged less than 6 months $(P$ values $=0.425$ and 0.134$)$. Conclusion: Knowledge and attitude of mothers and caregivers can influence complementary feeding for infants aged less than 6 months.
\end{abstract}

Keyword: Exclusive Breastfeeding, Toddler, Complementary Food (MPASI), Behavior

\begin{abstract}
ABSTRAK
Latar Belakang: Target pemberian ASI eksklusif yang belum tercapai disebabkan oleh pemberian Makanan Pendamping ASI (MPASI) yang diberikan lebih awal. Bayi usia 0-6 bulan seharusnya hanya diberikan ASI saja tanpa tambahan makanan pendamping apapun. Tujuan: Tujuan penulisan ini adalah menganalisis faktor yang berhubungan dengan perilaku ibu dalam memberikan makanan pendamping ASI (MPASI) di Kelurahan Pegirian. Metode: Desain penelitian menggunakan observasional cross sectional. Populasi pada penelitian adalah seluruh ibu dan pengasuh balita di kelurahan Pegirian dan sampel penelitian sebanyak 35 ibu dan pengasuh balita di RT 06 RW 02 Kelurahan Pegirian Kota Surabaya. Teknik sampling dengan menggunakan sampling jenuh atau metode sensus karena total populasi kurang dari 100. Variabel penelitian adalah latar belakang pendidikan, pendapatan, dan tindakan dalam pemberian MPASI. Data dianalisis dengan uji korelasi untuk melihat faktor yang hubungan. Hasil: Hasil penelitian menunjukkan bahwa ada hubungan antara pengetahuan dan sikap dengan perilaku pemberian MPASI ( $P$ value= 0,001 dan 0,015) dan tidak ada hubungan antara tingkat pendidikan dan status pekerjaan dengan perilaku pemberian MPASI pada bayi usia kurang 6 bulan ( $P$ value $=0,425$ dan 0 ,134). Kesimpulan: pengetahuan dan sikap ibu dan pengasuh balita dapat berpengaruh pada pemberian MPASI pada bayi usia kurang 6 bulan.
\end{abstract}

Kata Kunci : ASI eksklusif, Bayi, MPASI, Perilaku 


\section{PENDAHULUAN}

Sehat adalah kondisi yang terbebas dari segala macam penyakit baik secara fisik, mental maupun sosial (World Health Organization, 1948). Kondisi sehat dapat berupa adanya tingkat produktivitas yang baik secara fisik, mental, sosial maupun rohani yang bermanfaat untuk dirinya dan orang lain (Departemen Kesehatan Republik Indonesia, 2009b).

Masalah kesehatan di Indonesia sangat beragam dan kompleks. Masalah kesehatan ini dipengaruhi oleh beberapa faktor seperti faktor lingkungan yang mencakup lingkungan fisik, sosial, budaya dan politik. Faktor sarana dan prasarana kesehatan serta faktor perilaku seseorang juga mempengaruhi kesehatan (Blum, 1974).

Salah satu permasalahan kesehatan di Indonesia adalah cakupan pemberian Air Susu Ibu (ASI) eksklusif yang belum berhasil. United Nation Children Fund (UNICEF) dan World Health Organization (WHO) menganjurkan usaha penurunan angka kesakitan dan kematian anak dengan cara pemberian ASI yang sebaiknya diberikan minimal 6 bulan lamanya. ASI dapat diberikan kepada anak hingga usia 2 tahun dan diselingi dengan pemberian Makanan Pendamping ASI (MPASI) setelah anak usia 6 bulan (World Health Organization, 2009). Pemberian ASI eksklusif selama 6 bulan dianjurkan oleh Kementerian Kesehatan Republik Indonesia. Jenis makanan padat dan semi padat boleh diberikan kepada bayi setelah usia 6 bulan sebagai makanan pendamping selain ASI (Pusat Data dan Informasi Kementerian Kesehatan RI, 2014).

Target pencapaian ASI eksklusif di Indonesia belum tercapai, yang diharapkan yaitu sebesar $80 \%$. Tahun 2012 Survei Demografi dan Kesehatan Indonesia (SDKI) melaporkan bahwa pencapaian target ASI eksklusif di Indonesia adalah $42 \%$, sedangkan Dinas Kesehatan Provinsi melaporkan bahwa tahun 2013 cakupan bayi yang diberikan ASI eksklusif 0-6 bulan hanyalah 54,3\% (Pusat Data dan Informasi Kementerian Kesehatan RI, 2014).

Hasil pemantauan status gizi yang oleh Dirktorat Jenderal Kesehatan Masyarakat Kementerian Kesehatan pada tahun 2016 menunjukkan, Provinsi Jawa Timur belum mencapai target dalam hal cakupan pemberian ASI (31,3\%). Data dari Kabupaten dan Kota di Jawa Timur pada tahun 2016 didapatkan cakupan bayi yang mendapatkan ASI eksklusif sebesar 74\% saja. Pemerintah Provinsi Jawa Timur menetapkan target pencapaian ASI eksklusif yaitu sebesar 77\%, namun keseluruhan pencapian ASI eksklusif di Jawa Timur sebesar $74 \%$ sehingga belum mencapai target yang telah ditetapkan. Terdapat 23 Kabupaten dan Kota yang belum mencapai target salah satunya yaitu Kota Surabaya dengan presentase $55 \%$.

Salah satu wilayah dengan pencapaian pemberian ASI yang kurang adalah Kecamatan Semampir Kelurahan Pegirian (54\%). Data Puskesmas Pegirian Tahun 2017 menunjukkan cakupan ASI eksklusif sebesar $72,9 \%$ dengan rincian yaitu anak yang diberikan ASI Ekslusif sebanyak 148 anak, sementara yang tidak diberikan ASI eksklusif sebanyak 55 anak. Secara keseluruhan, pencapaian pemberian ASI eksklusif 6 bulan belum mencapai target yang ditetapkan oleh Indonesia yaitu 80\% (Dinas Kesehatan Kota Surabaya, 2016).

Hasil observasi yang dilakukan oleh pihak Puskesmas Pegirian menunjukkan bahwa salah satu faktor penyebab pemberian ASI eksklusif tidak tercapai yakni karena pemberian MPASI pada bayi tidak tepat. Bayi usia 0-6 bulan seharusnya hanya diberikan Asi Ekslusif saja tanpa makanan tambahan apapun. Peraturan Menteri Kesehatan nomor 450/Menkes/SK/IV/2004 merupakan peraturan baru yang dikeluarkan oleh Pemerintah Indonesia dari Menteri Kesehatan untuk menerapkan kode etik dari WHO, tentang waktu pemberian ASI eksklusif (Departemen Kesehatan Republik Indonesia, 2004). Peraturan nomor 237/1997 tentang Makanan Pendamping ASI (MPASI) yang diatur oleh Pemerintah, perlu ditegaskan bahwa MPASI bukan makanan pengganti ASI, tetapi makanan tambahan selain ASI yang diberikan setelah bayi usia 6 bulan (Departemen Kesehatan Republik Indonesia, 1997).

MPASI adalah makanan dan minuman yang diberikan kepada anak usia 6-24 bulan untuk pemenuhan kebutuhan gizinya. WHO bersama dengan Kementrian Kesehatan dan Ikatan Dokter Anak Indonesia (IDAI) telah menegaskan bahwa usia hingga 6 bulan hanya diberikan ASI eksklusif saja. Oleh karena itu, MPASI baru bisa diperkenalkan kepada bayi ketika bayi berusia 6 bulan keatas 
(Riksani, 2012). MPASI disebut sebagai makanan pergantian dari ASI ke makanan keluarga yang dilakukan secara bertahap baik dari jenis, frekuensi pemberian, jumlah porsi dan bentuk makanan yang disesuaikan dengan umur dan kemampuan bayi untuk mencerna makanan.

Aktivitas bayi setelah usia 6 bulan semakin banyak sehingga makanan pendamping dari ASI diperlukan guna memenuhi kebutuhan gizi untuk perkembangan dan pertumbuhan bayi. Mulai usia 6 bulan, bayi mengalami pertumbuhan yang sangat pesat sehingga bayi memerlukan asupan yang lebih banyak. Aktivitas bayi semakin banyak seperti mengangkat dada, berguling, merangkak, belajar duduk dan belajar berjalan sehingga perlu energi lebih banyak yang didapat dari asupan makanannya.

Tujuan dari pemberian MPASI adalah sebagai pelengkap zat gizi pada ASI yang kurang dibandingkan dengan usia anak yang semakin bertambah. Dengan usia anak bertambah maka kebutuhan zat gizi anak pun bertambah, sehingga perlu adanya MPASI untuk melengkapi. MPASI juga mengembangkan kemampuan anak untuk menerima berbagai variasi makanan dengan bermacam-macam rasa dan bentuk sehingga dapat meningkatkan kemampuan bayi untuk mengunyah, menelan, dan beradaptasi terhadap makanan baru.

Pemberian MPASI yang tidak tepat sangat berkaitan dengan faktor internal dari ibu bayi tersebut dan faktor eksternal yang dipengaruhi oleh lingkungan. Faktor internal meliputi pendidikan, pekerjaan, pengetahuan, sikap, tindakan, psikologis dan fisik dari ibu itu sendiri. Faktor eksternal meliputi faktor budaya, kurang optimalnya peran tenaga kesehatan, dan peran keluarga (Green, 1980).

Faktor internal merupakan faktor yang dipengaruhi dari individu sendiri untuk memutuskan tindakan pemberian MPASI. Teori Green menyebutkan ada 3 faktor penentu perubahan perilaku yaitu pendorong (predisposing), faktor pemungkin (enabling) dan faktor penguat (reinforcing) (Green, 1980).

Faktor pendorong merupakan faktor pemungkin seseorang untuk melakukan perubahan perilaku. Faktor ini meliputi rekognisi dan keputusan seseorang terkait kesehatan, pendidikan, sosial ekonomi dan sistem nilai yang dianut masyarakat (Green, 1980).

Ibu adalah seorang figur utama dalam keputusan untuk memberikan MPASI pada anaknya, apakah akan diberikan saat umur kurang 6 bulan atau saat setelah umur 6 bulan. Keputusan Ibu dalam pemberian MPASI tentunya didasari oleh pengetahuan ibu itu sendiri mengenai MPASI. Latar belakang pendidikan Ibu yang rendah belum tentu mempengaruhi pengetahuan Ibu mengenai MPASI. Tetapi dengan pengetahuan MPASI yang kurang maka akan mempengaruhi sikap dan tindakan Ibu dalam pemberian MPASI ini tidak tepat. Maka dari itu, perlu adanya peningkatan pengetahuan Ibu terlebih dahulu sehingga dengan pengetahuan Ibu baik maka diharapkan sikap dan tindakan Ibu dalam pemberian MPASI akan baik pula.

Umur seseorang menggambarkan banyak sedikitnya pengalaman dalam hidupnya (Notoatmojo, 2005). Usia responden pada penlitian ini yang lebih dari 50 tahun masih menganut kebiasaan nenek moyang yang erat kaitannya dengan budaya yang kebiasaan memberikan makanan selain ASI saat bayi usia kurang 6 bulan. Responden menganggap bahwa bayi kurang kenyang jika hanya diberikan susu saja sehingga bayi akan rewel. Selain itu juga agar bayi bisa beradaptasi dengan makanan orang dewasa.

Pekerjaan Ibu juga berpengaruh terhadap tindakan Ibu dalam pemberian MPASI. Status pekerjaan ibu akan mempengaruhi hubungan sosialnya terhadap banyak orang diluar rumah, sehingga memungkin lbu untuk memperoleh banyak informasi positif maupun negatif dari lingkungan sosial diluar rumah (Mulyaningsih, 2010). Anak dari ibu yang sibuk bekerja biasanya tidak mendapatkan ASI eksklusi. Kondisi ini berpotensi dalam pemberian makanan tambahan selain ASI kepada anaknya dan terlebih anak dititipkan pada pengasuh yang belum tentu mengerti tentang pemberian MPASI yang tepat.

Sikap Ibu dalam pemberian MPASI berperan penting untuk memutuskan suatu tindakan. Sikap merupakan respon atau reaksi seseorang yang belum melakukan tindakan apapun terhadap suatu stimulus atau objek tertentu yang diterima (Notoatmojo, 2012). Sikap seseorang didasari dengan pengetahuan yang baik, tetapi sikap yang baik belum 
tentu berpengaruh terhadap praktik atau tindakan seseorang dalam membuat keputusan. Diperlukan motivasi dari berbagai pihak untuk mengubah tindakan Ibu dalam pemberian MPASI yang tepat waktu.

Penjelasan tersebut menunjukkan bahwa waktu pemberian pertama MPASI yang kurang tepat sehingga rumusan masalah dalam penelitian ini berfokus pada faktor predisposisi yang berpengaruh pada tindakan seseorang dalam pemberian MPASI di wilayah Kelurahan Pegirian RW 02 RT 06, Kota Surabaya. Tujuan studi ini adalah untuk menggambarkan dari beberapa faktor predisposisi yang berhubungan dengan pengaruh ibu dalam memberikan MPASI sebelum anak usia 6 bulan.

\section{METODE}

Desain penelitian ini adalah analitik korelasional, yaitu mencari hubungan antara faktor-faktor predisposisi (pendorong) terhadap perilaku ibu dalam pemberian MPASI. Sampel penelitian ini adalah warga RT 06 RW 02 Kelurahan Pegirian, Kecamatan Semampir, Kota Surabaya. Teknik yang digunakan dalam menentukan sampel adalah dengan menggunakan sampling jenuh atau metode sensus, dimana seluruh jumlah populasi menjadi sampel. Metode ini digunakan karena total populasi sebanyak 40. Sampel penelitian ini sebanyak 35 responden.

Variabel penelitian yakni terdiri dari latar belakang pendidikan, pekerjaan, pengetahuan, sikap, dan tindakan dalam pemberian MPASI. Definisi operasional untuk masing-masing variabel adalah pemberian MPASI $<6$ bulan atau 6 bulan.

Data yang digunakan adalah data primer dan sekunder. Data primer diperoleh dari hasil kuesioner dan wawancara untuk mengetahui waktu pemberian pertama MPASI. Instrumen pengumpulan data primer menggunakan kuesioner dan panduan wawancara, sedangkan data sekunder diperoleh dari laporan cakupan ASI eksklusif tahun 2017 dari Puskesmas Pegirian.

Pengetahuan diukur dengan menjumlahkan jawaban benar kemudian mengkategorikan menjadi pengetahuan baik (76\%-100\%), cukup (56\%-75\%), dan kurang (<56\%). Sikap diukur menggunakan skala likert dengan kategori jawaban setuju (nilai 1) dan tidak setuju (nilai 0). Tindakan diukur dengan menggunakan jawaban ya atau tidak yang terdiri dari 9 pertanyaan dengan metode Skala Guttman yang menggunakan skala persentase antara $0-50 \%$ dengan kategori tidak memberikan MPASI <6 bulan, dan 51\% sampai $100 \%$ dengan kategori memberikan MPASI usia 6 bulan.

Data yang telah diperoleh kemudian diolah dan dianalisis setiap variabelnya. Analisa data dilakukan dengan cara uji korelasi dengan fisher exact untuk melihat hubungan antar variabel dan disajikan secara deskriptif yaitu dalam bentuk distribusi frekuensi.

\section{HASIL DAN PEMBAHASAN}

Hasil penelitian yang dilakukan di wilayah RT 06 RW 02 Kelurahan Pegirian, Kota Surabaya dari 35 responden yang diambil dari perwakilan setiap Kepala Keluarga (KK) diketahui bahwa masih banyak ibu yang memberikan makanan pendamping ASI kepada bayinya di usia kurang dari 6 bulan.

Tabel 1. Karakteristik Responden

\begin{tabular}{lll}
\hline \multirow{2}{*}{ Karakteristik } & \multicolumn{2}{c}{ Responden } \\
\cline { 2 - 3 } & \multicolumn{2}{c}{ n } \\
\hline Usia (Tahun) & & 11,4 \\
\hline $17-25$ & 4 & 34,3 \\
$26-35$ & 12 & 31,4 \\
$36-45$ & 11 & 11,4 \\
$46-55$ & 4 & 5,7 \\
$56-65$ & 2 & 5,7 \\
$>65$ & 2 & \\
\hline Pendidikan & & 74,3 \\
\hline Rendah & 26 & 25,7 \\
Menengah & 9 & 0 \\
Tinggi & 0 & \\
\hline Status Pekerjaan & \\
\hline Bekerja & 4 & 2,9 \\
Tidak Bekerja & 31 & 74,3 \\
\hline
\end{tabular}

Distribusi umur responden mulai dari 17 tahun hingga lebih dari 65 tahun. Klasifikasi umur pada rentang dari 17 hingga $>65$ tahun berdasarkan Departemen Kesehatan dibagi menjadi 6 (Departemen Kesehatan Republik Indonesia, 2009a). Keenam kategori tersebut antara lain:
1) Remaja akhir: 17 - 25 tahun
2) Dewasa awal: 26 - 35 tahun
3) Dewasa akhir: 36 - 45 tahun
4) Lansia awal: 46 - 55 tahun
5) Lansia akhir: 56 - 65 tahun 
6) Manula: 65 tahun keatas

Umur seseorang menggambarkan banyak sedikitnya pengalaman dalam hidupnya dan tentunya memiliki pengetahuan yang lebih banyak dari berbagai sumber yang didapat. Umur individu mempengaruhi tingkat kemampuan, kematangan dalam berfikir dan kemudahan seseorang dalam menerima informasi (Notoatmojo, 2003).

Undang-undang Nomor 2 Tahun 1989 menggolongkan level pendidikan formal menjadi yaitu:

1) Pendidikan tinggi, minimal pernah menempuh pendidikan di perguruan tinggi

2) Pendidikan menengah, adalah pendidikan setara SMP dan SMA

3) Pendidikan rendah yaitu tingkat SD (Pemerintah Republik Indonesia, 1989)

Pendidikan merupakan faktor penentu mudah atau tidaknya individu dalam memahami informasi yang diperoleh. Semakin tinggi pendidikan individu maka semakin baik pengetahuannya (Notoatmojo, 2007).

Distribusi responden berdasarkan pendidikan terbanyak adalah tamat SD sebanyak $24(68,60 \%)$ dan hanya $2(5,7 \%)$ responden yang tamat SMA/SMK. Latar belakang pendidikan belum tentu mempengaruhi pada tingkat pengetahuan Ibu terkait MPASI. Pengetahuan seseorang dipengaruhi oleh tingkat pendidikan. Pendidikan dapat berlangsung didalam maupun diluar sekolah sebagai upaya untuk mengembangkan kepribadian dan kemampuan seseorang. Proses belajar juga dipengaruhi oleh pendidikan. Semakin tinggi pendidikan individu semakin mudah individu tersebut untuk menerima informasi. Banyaknya informasi yang didapatkan maka semakin banyak pula pengetahuan yang didapatkan seseorang. Tetapi tidak selamanya tingkat pendidikan mutlak dapat mempengaruhi pengetahuan seseorang. Bisa jadi pengetahuan seseorang baik karena didapat dari lingkungan sosial mereka.

Ibu yang bekerja mempunyai risiko untuk memberikan MPASI tidak tepat waktu yaitu pada usia kurang 6 bulan. Pada dasarnya Ibu yang memiliki kesibukan bekerja diluar rumah tidak memiliki banyak waktu untuk memberikan ASI secara eksklusif pada anaknya, sehingga berpotensi untuk memberikan makanan tambahan selain ASI sejak anak usia kurang 6 bulan.
Penelitian yang dilaksanakan di Rumah Sakit Muhammadiyah Lamongan menunjukkan bahwa faktor determinan paling kuat yang menghalangi keberhasilan pemberian ASI eksklusif adalah pemberian MPASI dini yaitu usia anak <6 bulan (Kurniawan, 2013). Penelitian lain menunjukkan bahwa sebesar 68,8\% ibu akan memberikan ASI eksklusif karena mendapat motivasi dari teman kerja dibandingkan dengan ibu yang tidak mendapatkan motivasi dari teman kerja akan berpotensi tidak memberikan ASI eksklusif. Sehingga dapat disimpulkan bahwa ibu yang bekerja dan memiliki teman kerja akan lebih memperhatikan pemberian ASI ekslusif karena mendapatkan motivasi dari teman kerjanya (Septiani, Budi and Karbito, 2017).

Hasil dari penelitian yang dilakukan di RT 06 RW 02 Kelurahan Pegirian Kota Surabaya melalui penyebaran kuesioner dengan 35 responden diketahui sebanyak 22 Ibu yang memberikan MPASI pada anaknya saat usia <6 bulan dan sebanyak 13 lbu memberikan MPASI pertama pada bayinya usia 6 bulan atau lebih dari 6 bulan. Pemberian MPASI yang terlalu dini mempunyai risiko terjadinya diare dan dalam jangka waktu lama dapat mengakibatkan terjadinya Kurang Energi Protein (KEP) pada anak balita (Sasongko, 2012; Maelana, 2017).

Tabel 2. Distribusi Tindakan Responden dalam Pemberian MPASI

\begin{tabular}{lll}
\hline Pemberian Pertama MPASI & $\mathbf{n}$ & $\%$ \\
\hline Usia<6 Bulan & 22 & 62,9 \\
Usia 6 Bulan & 13 & 37,1 \\
\hline Total & 35 & 100 \\
\hline
\end{tabular}

Waktu pemberian MPASI yang tidak tepat dapat mengakibatkan berbagai masalah kesehatan khususnya pada pencernaan seperti diare, konstipasi infeksi usus, dan lain sebagainya. Hasil penelitian sebelumnya menunjukkan bahwa sebanyak $89,8 \%$ ibu yang memberikan MPASI pada waktu yang tepat, maka bayi cenderung memiliki status gizi baik, sedangkan ibu dengan pemberian MPASI yang tidak tepat waktu akan memiliki status gizi kurang yaitu sebesar 8,3\% (Nur, 2014).

Penelitian di Puskesmas Rowotengah, Kabupaten Jember menunjukkan bahwa terdapat hubungan antara status gizi bayi usia 0-6 bulan 
dengan pemberian MPASI dini. Pemberian MPASI yang tidak tepat waktu terhadap status status gizi bayi didapatkan bahwa terdapat $16(69.6 \%)$ bayi jarang artinya hampir tidak memberikan MPASI pada usia kurang 6 bulan memiliki status gizi baik dan terdapat $13(48.1 \%)$ bayi yang sering diberikan MPASI dini memiliki status gizi kurang (Wargiana, Susumaningrum and Rahmawati, 2013).

Data WHO tahun 2010 didapatkan bahwa sebesar $51 \%$ penyebab kematian balita karena penyakit Pneumonia, Diare, Campak dan Malaria. Sebesar 54\% kematian balita erat hubungannya dengan status gizi balita (World Health Organization, 2010).

Penelitian yang dilakukan di Sedayu menyebutkan bahwa anak yang mendapatkan MPASI tidak tepat waktu pemberiannya mempunyai risiko 2,8 kali untuk menjadi stunting dengan $z$ score <2. Hasil ini memiliki makna bahwa kejadian stunting memiliki hubungan yang signifikan dengan waktu mulai pemberian MPASI (Dwi, 2016).

Hasil penelitian sebelumnya yang dilakukan di Jakarta didapatkan bahwa tidak ada hubungan yang signifikan antara usia Ibu dengan tindakan pemberian makanan pendamping ASI $(P$ value = 0,645 ) serta hubungan antara lbu dengan bayi $(P$ value $=0,724)$, selain itu menunjukkan bahwa tidak ada hubungan yang signifikan antara faktor predisposisi dengan tindakan pemberian makanan pendamping ASI. Sebaliknya, ada korelasi yang signifikan antara pendidikan pengasuh/lbu dan pengetahuan dengan waktu mulai memberikan makanan pendamping ASI. Selain itu menunjukkan bahwa pendidikan dan pengetahuan adalah variabel pelindung pada praktik pemberian makanan pendamping $(O R=$ 0,237 dan 0,216) artinya bahwa ibu yang memiliki pendidikan tinggi dan pengetahuan yang lebih baik cenderung melakukan praktik pemberian makanan tambahan yang baik dan tepat pada waktunya (Septriana and Suhartono, 2016).

MPASI sebaiknya diberikan setelah bayi usia 6 bulan (Prabantini, 2010). Alasan pentingnya menunda pemberian makanan selain ASI sampai bayi menginjak usia 6 bulan yakni antara lain:

1. Bayi hanya membutuhkan ASI sebagai makanan dan minumannya sampai usia 6 bulan.
ASI adalah makanan yang memiliki nutrisi dan energi tinggi yang mudah dicerna oleh bayi. Pencernaan bayi lebih mudah mencerna protein dan lemak yang berasal dari ASI. ASI mengandung kurang lebih 100 bahan yang tidak bisa ditemukan dalam susu sapi maupun susu buatan pabrik. Terlebih pada bulan pertama dimana kondisi bayi dalam keadaan yang paling rentan terhadap penyakit, sehingga ASI eksklusif membantu untuk melindungi bayi dari berbagai penyakit infeksi.

2. ASI dapat memberikan perlindungan pada bayi

Bayi mendapatkan kekebalan tubuh melalui ASI. Lebih dari 50 bahan ASI mengandung faktor imunitas. Hasil penelitian menunjukkan bahwa 40\% bayi yang diberikan ASI eksklusif sampai usia 4 bulan lebih sedikit terkena infeksi dibanding dengan bayi yang diberi ASI eksklusif dan makanan tambahan pendamping ASI lainnya di usia kurang dari 4 bulan. Pemberian MPASI terlalu dini ibarat seperti mempermudah jalan masuknya berbagai jenis kuman kedalam tubuh bayi, terlebih jika makanan tidak disajikan secara higienis.

3. Menunggu kematangan pada sistem pencernaan bayi agar berkembang lebih sempurna.

Pertumbuhan sistem pencernaan maupun psikologis bayi pada umur 6-9 bulan, biasanya bayi sudah siap menerima makan padat. Belum siapnya sistem pencernaan bayi, maka makanan padat tidak dapat dicerna dengan baik sehingga akan mengakibatkan gangguan pencernaan seperti konstipasi/sembelit, diare, infeksi usus, dan gangguan pencernaan lainnya.

4. Mengurangi risiko alergi pada makanan

Meningkatkan durasi waktu pemberian ASI eksklusif dapat memperkecil risiko terjadinya alergi pada makanan. Bakteri patogen penyebab berbagai macam penyakit infeksi dapat masuk ke dalam tubuh bayi bersama kandungan protein yang terdapat di makanan. Organ pencernaan bayi dilapisi oleh antibodi (sigA) yang menyediakan kekebalan pasif, sehingga antibodi tersebut dapat 
mengurangi terjadinya penyakit dan reaksi alergi pada bayi.

5. Membantu melindungi bayi dari anemia.

Untuk mengurangi anemia, bayi umur 6 bulan baru diperkenalkan dengan makanan dan suplemen yang mengandung zat besi. Dengan pencernaan bayi yang sudah sempurna, diharapkan pencernaan mampu menyerap zat besi dengan baik.

6. Penundaan MPASI dapat membantu ibu dalam menjaga produksi ASI

Semakin banyak bayi mendapatkan makanan padat, maka semakin sedikit susu yang dihisap oleh bayi. Sedikitnya susu yang dihisap bayi, akan sedikit pula produksi ASI. Sehingga bayi banyak makan makanan padat pada usia lebih dini cenderung akan lebih cepat disapih artinya lebih cepat berhenti minum susu dari ibunya.

7. Pemberian MPASI pada waktu terlalu dini dapat berakibat obesitas dikemudian hari

Makanan padat yang diberikan tidak tepat waktunya akan meningkatkan kandungan lemak sehingga mempengaruhi berat badan pada anak-anak dimasa yang akan datang. Berat badan berlebih akan mengembangkan penyakit kronis seperti diabetes dan jantung.

8. Bayi belum memiliki kemampuan yang baik untuk mengendalikan otot-otot tenggorokan dan lidah untuk menelan makanan padat.

Karena pemberian makanan padat terlalu dini, akan menjadikan bayi kesulitan dalam proses menelan dan mudah tersedak. Refleks lidah masih sangat kuat dan pemberian makanan padat akan menyulitkan untuk ditelan.

Responden berpendapat bahwa penyebab pemberian MPASI $<6$ bulan yang banyak dilakukan karena adanya ajaran nenek moyang dahulu yang mengajarkan MPASI diberikan pada bayi <6 bulan sebanyak 26 orang. Kurangnya pengetahuan ibu dan pengasuh terhadap waktu pemberian MPASI sebanyak 3 orang. Ibu beranggapan supaya bayi tidak rewel sebanyak 21 orang. Alasan karena lbu bekerja dan tidak memiliki banyak waktu untuk memompa ASI di tempat kerja, sehingga ibu beranggapan bayi memerlukan makanan tambahan yaitu sebanyak 1 orang. Selain tidak memiliki banyak waktu, ibu bekerja juga akan menitipkan anaknya kepada nenek atau pengasuh yang belum tentu tahu mengenai waktu pemberian MPASI yang tepat. Alasan lain karena ASI tidak keluar sebanyak 3 orang. Terdapat pula ibu yang beranggapan bahwa jika hanya susu saja yang diberikan bayi akan merasa tidak kenyang dan menangis terus.

Tabel 3. Distribusi Penyebab Ibu Memberikan MPASI Usia <6 Bulan

\begin{tabular}{lll}
\hline $\begin{array}{l}\text { Penyebab Pemberian } \\
\text { MPASI <6 Bulan }\end{array}$ & \multicolumn{1}{c}{ f } & \multicolumn{1}{c}{$\%$} \\
\hline Ajaran nenek moyang & 26 & 45,5 \\
Kurang pengetahuan Ibu & 3 & 5,25 \\
Supaya bayi tidak rewel & 21 & 36,75 \\
lbu bekerja & 1 & 1,75 \\
ASI tidak keluar & 3 & 5,25 \\
\hline
\end{tabular}

MPASI yang tidak tepat pemberiannya karena ajaran dari nenek moyang yang turun temurun yang beranggapan bahwa jika bayi hanya diberikan susu saja bayi kurang tenaga dan sering rewel karena lapar jika diberikan susu saja. Kondisi tersebut disebabkan karena kemungkinan nenek moyang terdahulu masih rendah pendidikannya sehingga kurang memahami tentang pemberian MPASI yang tepat. Penelitian sebelumnya menyebutkan bahwa ada korelasi yang signifikan antara tingkat pendidikan pengasuh dengan pengetahuan terkait makanan pendamping ASI ( $P$ value $=0,012$ dan $P$ value $=0,005)$. Dijelaskan juga bahwa tindakan seseorang berawal dari pengetahuan yang didapatkan selama seseorang mengenyam pendidikan formal ataupun pendidikan non formal (Septriana and Suhartono, 2016).

Hasil penelitian pada Tabel 4, dapat dilihat distribusi responden berdasarkan variabel independen terhadap faktor predisposisi pada pemberian MPASI pertama yang disajikan dalam bentuk frekuensi. Tabel 4 diketahui bahwa semua responden yang mempunyai pengetahuan cukup dan kurang memberikan MPASI pertama pada bayi di usia kurang dari 6 bulan yaitu sebesar 100\%. Dilihat dari sikap responden, responden yang mendukung pemberian MPASI pertama di usia kurang 6 bulan yaitu sebesar $51,85 \%$. Tidak berbeda jauh, sebesar 48,15\% responden mendukung pemberian MPASI di usia setelah 6 bulan. 
Dilihat dari tingkat pendidikan, responden yang memiliki tingkat pendidikan rendah ternyata sebagian besar memberikan MPASI pertama di usia kurang 6 bulan yaitu sebesar $69,3 \%$. Masih terdapat pula responden dengan tingkat pendidikan menengah yang memberikan MPASI pertama di usia $<6$ bulan yaitu sebesar 44,4\%. Responden yang tidak bekerja, lebih banyak memberikan MPASI pertama di usia kurang 6 bulan yaitu sebesar $67,7 \%$.

Faktor predisposisi yang berhubungan dengan pemberian MPASI pertama di Kelurahan Pegirian dianalisa dengan crosstabs. Pada variabel pengetahuan menggunakan uji statistik korelasi, sedangkan variabel sikap, pendidikan dan status pekerjaan menggunakan Fisher Exact.

\section{Hubungan Pengetahuan dengan Tindakan Ibu dalam Pemberian MPASI}

Pengetahuan disebut sebagai hasil tahu terhadap objek tertentu setelah seseorang melakukan penginderaan. Penginderaan terjadi melalui panca indra manusia melalui mata, telinga, hidung, lidah dan kulit (Wawan and Dewi, 2011).

Tabel 4. Distribusi Frekuensi Responden berdasarkan Variabel Independen terhadap Faktor Predisposisi pada Pemberian MPASI Pertama

\begin{tabular}{|c|c|c|c|c|c|}
\hline \multirow{3}{*}{ Variabel } & \multicolumn{4}{|c|}{ Pemberian MPASI Pertama } & \multirow{3}{*}{ Total } \\
\hline & \multicolumn{2}{|c|}{ Usia <6 Bulan } & \multicolumn{2}{|c|}{ Usia 6 Bulan } & \\
\hline & Frekuensi & Persentase & Frekuensi & Persentase & \\
\hline \multicolumn{6}{|l|}{ Pengetahuan } \\
\hline Baik & 6 & 31,6 & 13 & 68,4 & 19 \\
\hline Cukup & 8 & 100 & 0 & 0 & 8 \\
\hline Kurang & 8 & 100 & 0 & 0 & 8 \\
\hline \multicolumn{6}{|l|}{ Sikap } \\
\hline Mendukung & 14 & 51,85 & 13 & 48,15 & 27 \\
\hline Tidak mendukung & 8 & 100 & 0 & 0 & 8 \\
\hline \multicolumn{6}{|l|}{ Tingkat pendidikan } \\
\hline Pendidikan rendah & 18 & 69,3 & 8 & 30,7 & 26 \\
\hline Pendidikan menengah & 4 & 44,4 & 5 & 55,6 & 9 \\
\hline \multicolumn{6}{|l|}{ Status pekerjaan } \\
\hline Bekerja & 1 & 25 & 3 & 75 & 4 \\
\hline Tidak bekerja & 21 & 67,7 & 10 & 32,3 & 31 \\
\hline
\end{tabular}

Tabel. 5 Hasil Analisis Variabel dengan Crosstabs

\begin{tabular}{|c|c|c|c|c|c|}
\hline \multirow{2}{*}{ Variabel } & \multicolumn{2}{|c|}{ Pemberian MPASI Pertama } & \multirow[b]{2}{*}{ a } & \multirow{2}{*}{$\begin{array}{c}P \\
\text { Value }\end{array}$} & \multirow{2}{*}{ Keterangan } \\
\hline & Usia <6 Bulan (\%) & Usia 6 Bulan (\%) & & & \\
\hline \multicolumn{6}{|l|}{ Pengetahuan } \\
\hline Baik & 31,6 & 68,4 & \multirow{3}{*}{0,05} & \multirow{3}{*}{0,001} & \multirow{3}{*}{ Signifikan } \\
\hline Cukup & 100 & 0 & & & \\
\hline Kurang & 100 & 0 & & & \\
\hline \multicolumn{6}{|l|}{ Sikap } \\
\hline Mendukung & 51,85 & 48,15 & \multirow[t]{2}{*}{0,05} & \multirow[t]{2}{*}{0,015} & \multirow[t]{2}{*}{ Signifikan } \\
\hline Tidak mendukung & 100 & 0 & & & \\
\hline \multicolumn{6}{|l|}{ Tingkat pendidikan } \\
\hline Rendah & 69,3 & 30,7 & \multirow{2}{*}{0,05} & \multirow{2}{*}{0,425} & \multirow{2}{*}{$\begin{array}{c}\text { Tidak } \\
\text { signifikan }\end{array}$} \\
\hline Menengah & 44,4 & 55,6 & & & \\
\hline \multicolumn{6}{|l|}{ Status pekerjaan } \\
\hline Bekerja & 25 & 75 & \multirow{2}{*}{0,05} & \multirow{2}{*}{0,134} & \multirow{2}{*}{$\begin{array}{c}\text { Tidak } \\
\text { signifikan }\end{array}$} \\
\hline Tidak bekerja & 67,7 & 32,3 & & & \\
\hline
\end{tabular}

Pengetahuan adalah hasil tahu seseorang terhadap objek yang diamati melalui panca indera yang dimilikinya yaitu mata, telinga, hidung dan panca indera lainnya (Notoatmodjo, 2010). Kategori pengukuran pengetahuan dibagi menjadi tiga, antara lain:

1. Pengetahuan baik, apabila mendapat nilai sebesar $76-100 \%$
2. Pengetahuan cukup, apabila mendapat nilai sebesar $56-75 \%$

3. Pengetahuan kurang, apabila mendapat nilai kurang $56 \%$ (Machfoedz and Suryani, 2009).

Hasil crosstabs dengan uji korelasi didapatkan bahwa ada hubungan yang signifikan antara tingkat pengetahuan dengan tindakan lbu untuk memberikan 
makanan komplementer/MPASI $(P$ value $=$ $0,001)$. Hasil ini sesuai dengan penelitian yang dilakukan di Karo, Sumatera Utara. Penelitian tersebut mengungkapkan bahwa hubungan yang signifikan antara tingkat pengetahuan dengan tindakan pemberian MPASI $(P$ value $=0,001)$ (Ginting, Sekarwarna and Sukandar, 2015). Penelitian lain juga menunjukkan hasil serupa, dimana diperoleh hasil terdapat korelasi antara pengetahuan ibu dengan praktik pemberian makan komplementer/MPASI $(P$ value $=0,005)$ (Septriana and Suhartono, 2016). Hasil ini juga diperkuat oleh penelitian lain pada 2018 yang menunjukkan bahwa ada hubungan antara tingkat pengetahuan ibu dan pengasuh terhadap tindakan ibu untuk memberikan makanan padat pada bayinya di usia 6-12 bulan (Artika and Arty, 2018).

\section{Hubungan Sikap dengan Tindakan Ibu Terhadap Pemberian MPASI}

Sikap seseorang merupakan suatu bentuk respon yang belum terlihat nyata. Sikap belum melakukan suatu tindakan yang terjadi nyata, tetapi masih berupa pemahaman dan persiapan seseorang untuk bereaksi terhadap stimulus yang diperoleh dari lingkungan sekitarnya. Hasil crosstabs dengan uji statistik Fisher Exact didapatkan bahwa ada hubungan yang bermakna antara sikap dengan tindakan Ibu dalam pemberian MPASI pada bayinya di usia kurang 6 bulan ( $P$ value $=$ 0,015).

Penelitian yang dilakukan di Kabupaten Karo, Sumatera Utara juga memperoleh hasil yang sama bahwa terdapat hubungan signifikan antara sikap Ibu dengan tindakan ibu memberikan MPASI pada anaknya di usia kurang 6 bulan $(P$ value $=0,001)$. Hasil penelitian di Kalimantan Selatan juga menunjukkan bahwa terdapat hubungan sikap Ibu yang memiliki kategori "baik" mempunyai risiko kecil untuk memberikan MPASI pada bayi usia kurang 6 bulan. Rangsangan dari lingkungan akan mendorong sikap seseorang untuk bersiap melakukan aksi. Sikap menentukan akan aksi seseorang tergantung dari stimulus yang diperoleh (Fathurrahman, 2004).

\author{
Hubungan Latar Belakang Pendidikan \\ Responden terhadap Tindakan \\ Pemberian MPASI
}

Hasil crosstabs dengan uji statistik Fisher exact antara latar belakang pendidikan dengan tindakan pemberian MPASI menunjukkan bahwa tidak ada hubungan yang bermakna $(P$ value $=$ 0,425). Hasil penelitian tersebut sesuai dengan penelitian yang dilakukan di Karo, Sumatera Utara bahwa nilai $P$ value = $0,360$ ( $P$ value $>0,05)$ sehingga dapat disimpulkan tingkat pendidikan ibu tidak berpengaruh terhadap pemberian MPASI pada bayi < 6 bulan (Ginting, Sekarwarna and Sukandar, 2015).

Berbeda dengan hasil penelitian yang dilakukan di Nigeria menyebutkan bahwa pemberian MPASI pada anak yang tidak tepat waktu berpengaruh terhadap tingkat pendidikan ibunya. Penelitian tersebut juga menyatakan bahwa ibu yang mempunyai level pendidikan rendah berpotensi besar untuk memberikan MPASI sejak dini kepada anaknya karena kurangnya pengetahuan ibu terkait waktu pemberian MPASI yang tepat (Agho et al., 2011). Hasil serupa juga ditunjukkan oleh penelitian yang dilakukan di Jakarta, bahwa terdapat korelasi yang signifikan pada pendidikan dan pengetahuan ibu terhadap makanan pendamping ASI dengan $P$ value $=0,012$ dan $P$ value $=$ 0,005 (Septriana and Suhartono, 2016).

\section{Hubungan Status Bekerja Responden terhadap Tindakan Pemberian MPASI \\ Hasil crosstabs dengan uji statistik} Fisher Exact bahwa tidak ada hubungan yang signifikan antara status bekerja dengan tindakan Ibu dalam pemberian MPASI pada bayinya $(P$ value $=1,00)$. Berbeda dengan hasil penelitian yang dilakukan di Karo, Sumatera Utara yang menunjukkan bahwa terdapat pengaruh yang bermakna antara status pekerjaan ibu terhadap waktu pemberian MPASI kepada anaknya (Ginting, Sekarwarna and Sukandar, 2015). Hasil analisis juga diperoleh nilai $R P=1,91$, artinya ibu yang sibuk bekerja memiliki potensi sebesar 1,91 kali untuk memberikan makanan pendaping ASI sejak dini yaitu di usia kurang 6 bulan. 
Ibu yang bekerja biasanya memiliki kesibukan dan tidak mempunyai banyak waktu untuk mengurusi anaknya, sehingga kemungkinan anak akan dititipkan kepada pengasuh atau neneknya. Hasil penelitian yang dilakukan di Peninsular Malaysia juga menunjukkan bahwa status pekerjaan Ibu berpengaruh terhadap tindakan ibu untuk memberikan MPASI dini pada bayinya di usia kurang dari 6 bulan (Scott et al., 2009).

\section{SIMPULAN}

Mayoritas responden telah memberikan MPASI pada bayi sebelum berusia 6 bulan. Kondisi ini terjadi karena tindakan tersebut merupakan bagian dari ajaran nenek moyang.

Tidak ada hubungan yang signifikan antara tingkat pendidikan dan status pekerjaan dengan pemberian MPASI. Terdapat hubungan yang signifikan antara pengetahuan dan sikap ibu dengan pemberian MPASI pada bayi $<6$ bulan.

\section{DAFTAR PUSTAKA}

Agho, K. E. et al. (2011) 'Determinants of exclusive breastfeeding in Nigeria', BMC Pregnancy and Childbirth, 11(1), p. 2. doi: 10.1186/1471-2393-11-2.

Artika, as M. and Arty, D. (2018) 'Hubungan Pengetahuan Ibu dengan Pemberian Makanan Pendamping ASI Pada bayi Usia 6 - 12 Bulan', in The 7th University Research Colloqium 2018.

Blum, H. L. (1974) Planning for Health: Development and Application of Scocial Change Theory. New York: Behavioral Publication.

Departemen Kesehatan Republik Indonesia (1997) 'Kepmenkes No. 237 Tahun 1997 tentang Pemasaran Pengganti Air Susu Ibu'. Jakarta: Kementerian Kesehatan RI.

Departemen Kesehatan Republik Indonesia (2004) 'Kepmenkes No. 450 Tahun 2004 tentang Pemberian ASI.' Jakarta.

Departemen Kesehatan Republik Indonesia (2009a) Profil Kesehatan Indonesia 2008. Jakarta.

Departemen Kesehatan Republik Indonesia (2009b) Undang-undang Republik Indonesia Nomor 36 Tahun 2009 tentang Kesehatan. Jakarta.

Dinas Kesehatan Kota Surabaya (2016) Profil Kesehatan Tahun 2016.
Surabaya.

Dwi, P. K. (2016) Hubungan antara Pemberian Makanan Pendamping ASI (MP-ASI) dengan Kejadian Stunting Anak Usia 6-23 Bulan di Kecamatan Sedayu. Universitas Alma Ata.

Fathurrahman (2004) Pemberian ASI dan Makanan Pendamping ASI pada Bayi $<6$ bulan oleh Ibu-ibu Suku Banjar di Perkotaan dan Pedesaan di Kalimantan Selatan. Universitas Gadjah Mada.

Ginting, D., Sekarwarna, N. and Sukandar, H. (2015) 'Pengaruh Karakteristik, Faktor Internal dan Eksternal Ibu terhadap Pemberian MP-ASI pada Bayi Usia < 6 Bulan di Wilayah Kerja Puskesmas Barusjahe Kabupaten Karo Provinsi Sumatera Utara', Jurnal Ilmu Kesehatan, (38), pp. 1-13.

Green, L. (1980) Health Education: A Diagnosis Approach. United State: Mayfield Publishing Co.

Kurniawan, B. (2013) 'Determinan Keberhasilan Pemberian Air Susu Ibu Eksklusif', Jurnal Kedokteran Brawijaya, 27(4), pp. 236-240.

Machfoedz, I. and Suryani, E. (2009) Pendidikan Bagian dari Promosi Kesehatan. Yogyakarta: Fitramaya.

Maelana, S. (2017) 'Hubungan Ketepatan Pemberian Makanan Pendamping Air Susu Ibu (MP-ASI) dengan Kejadian Diare pada Bayi Usia 1-12 Bulan di Puskesmas Umbulharjo I', Program Studi DIV Bidan Pendidik, Fakultas Ilmu Kesehatan Universitas Aisyiyah Yogyakarta.

Mulyaningsih, A. (2010) Persepsi Ibu Bekerja terhadap Implementasi ASI Eksklusif (Kasus Kelurahan Karadenan Kecamatan Cibinong Kabupaten Bogor). Bogor: Institut Pertanian Bogor.

Notoatmodjo, S. (2010) Ilmu Perilaku Kesehatan. Jakarta: Rineka Cipta.

Notoatmojo, S. (2003) Pendidikan Dan Perilaku Kesehatan. Jakarta: Rineka Cipta.

Notoatmojo, S. (2005) Metode Penelitian Kesehatan, edisi revisi. Jakarta: Rineka Cipta.

Notoatmojo, S. (2007) Promosi Kesehatan dan Ilmu Perilaku. Jakarta: Rineka Cipta.

Notoatmojo, S. (2012) Promosi Kesehatan dan Ilmu Perilaku. Jakarta: Rineka Cipta.

Nur, D. (2014) Hubungan Pemberian 
Makanan Pendamping ASI (MPASI) dengan Status Gizi pada Anak Usia 1 2 Tahun di Yogyakarta. Sekolah Tinggi Ilmu Kesehatan 'Aisyiyah, Yogyakarta.

Pemerintah Republik Indonesia (1989) 'Undang-undang Republik Indonesia Nomor 2 Tahun 1989 tentang Sistem Pendidikan Nasional'. Jakarta.

Prabantini, D. (2010) A to Z Makanan Pendamping ASI. Yogyakarta: Andi.

Pusat Data dan Informasi Kementerian Kesehatan RI (2014) Situasi dan Analisis ASI Eksklusif. Jakarta.

Riksani, R. (2012) Variasi Olahan Makanan Pendamping ASI. Jakarta Timur: Dunia Kreasi.

Sasongko, A. (2012) 'Hubungan antara Pemberian MP-ASI dengan di Kecamatan Pedan Kabupaten', Sekolah Tinggi Ilmu Kesehatan 'Aisyiyah, Yogyakarta.

Scott, J. A. et al. (2009) 'Predictors of the early introduction of solid foods in infants: results of a cohort study', BMC pediatrics. BioMed Central, 9, p. 60. doi: 10.1186/1471-2431-9-60.

Septiani, H., Budi, A. and Karbito, K. (2017) 'Faktor-Faktor yang Berhubungan dengan Pemberian ASI Eksklusif Oleh Ibu Menyusui yang Bekerja Sebagai Tenaga Kesehatan', Jurnal Aisyah : Jurnal Ilmu Kesehatan, 2, p. 159. doi: 10.30604/jika.v2i2.62.
Septriana and Suhartono, G. A. (2016) 'Predisposing factors of complementary feeding practices among 9-11 month-old infants in Jakarta urban slum area', Kesmas, 10(3), pp. 127-133. doi: 10.21109/kesmas.v10i3.948.

Wargiana, R., Susumaningrum, L. A. and Rahmawati, I. (2013) 'Hubungan Pemberian MP-ASI Dini dengan Status Gizi Bayi Umur 0-6 Bulan di Wilayah Kerja Puskesmas Rowotengah Kabupaten Jember', Pustaka Kesehatan; Vol 1 No 1 (2013). Available at: https://jurnal.unej.ac.id/index.php/J $\mathrm{PK} /$ article/view/519.

Wawan, A. and Dewi (2011) Teori dan Pengukuran Pengetahuan Sikap dan Perilaku Manusia. Yogyakarta: Nuha Medika.

World Health Organization (1948) Constitution of World Health Organization. Available at: https://www.who.int/about/who-weare/constitution.

World Health Organization (2009) Infant and Young Child Feeding. Geneva: World Health Organization.

World Health Organization (2010) World Health Statistics, World Health Statistics. France. 